\title{
Fundamentals of Accounting Losses
}

\author{
April Klein and Carol Marquardt \\ Stern School of Business \\ New York University \\ 44 W. $4^{\text {th }}$ Street \\ New York, NY 10012
}

We wish to thank Sudipta Basu, Carla Hayn, Lee-Seok Hwang, Doug Skinner, Ross Watts, Christine Wiedman, and participants at the accounting workshop at New York University and the AAA Meeting in Atlanta for their valuable comments and suggestions. 


\title{
Fundamentals of Accounting Losses
}

\begin{abstract}
This paper examines accounting and non-accounting factors behind accounting losses over a fifty-year period. Using multivariate time-series analysis, we report evidence that the annual percentage of losses for U.S. firms is significantly related to accounting conservatism, Compustat coverage of small firms, real firm performance as measured by cash flows from operations, and business cycle factors. We further find that non-accounting factors tend to play the dominant role in explaining accounting losses over our sample period. Our results are robust to alternative definitions of macroeconomic productivity, as well as to varying model specifications. Our findings contribute to the literature on accounting losses and accounting conservatism and have implications for the use of accounting loss information in numerous settings.
\end{abstract}

Keywords: Accounting losses; accounting conservatism; business cycle; macroeconomics; cash flows from operations.

Data availability: All data employed in this study are commercially available from the sources described in the text. 


\section{INTRODUCTION}

Over the last fifty years, as the proportion of firms reporting negative income has increased, many studies have examined various aspects of accounting losses. One strand of research investigates how losses relate to various outcomes, such as security valuation (Collins et al. 1997; Barth et al. 1998; Joos and Plesko 2005), bankruptcy (Barth et al. 1998), and the abandonment option (Hayn 1995; Joos and Plesko 2005). These studies find that non-earnings information, most prominently the book value of equity, takes on a higher degree of relevance for loss firms than for profit firms. Another line of research examines accounting properties associated with negative income. For example, Givoly and Hayn (2000) demonstrate a fall in the return on assets (ROA) over time and attribute this phenomenon to an increase in accounting conservatism, as reflected by non-operating accruals. Joos and Plesko (2005) show that investors can assess the likelihood that a firm's negative income will persist (or reverse) over time by examining cash flow and accrual components of losses.

The purpose of our study is to investigate the incremental roles that several fundamental non-accounting factors play in generating accounting losses over and beyond accounting conservatism. Using aggregated time-series data over a fifty-year sample period, 1951-2001, we first show a significantly positive temporal association between accounting losses and accounting conservatism, a result consistent with Givoly and Hayn (2000). We build on these results by adding firm size, real performance as measured using cash flows from operations (CFO), and business cycle effects to a multivariate regression of the frequency of accounting losses on conservatism and these additional factors. Our main findings are twofold. First, after controlling for accounting 
conservatism, the frequency of accounting losses is positively related to the proportion of small firms reported on Compustat and negatively related to firms' $\mathrm{CFO}$ and to macroeconomic productivity. Second, while accounting conservatism remains a significant determinant of accounting losses, its overall contribution is lessened considerably when placed alongside the other independent variables. This effect is especially magnified when, as a sensitivity test, we replace loss frequency with median ROA and repeat our analysis; here we find that only the non-accounting factors are significant determinants of profitability levels over time. Overall, our results suggest that while both accounting and non-accounting factors are systematically related to accounting losses, non-accounting factors tend to play the dominant role.

In additional sensitivity tests, we use alternative measures of accounting conservatism and the business cycle in our regression analyses. Our non-accounting determinants remain robust to whether we use non-operating accruals, an earnings-return metric (Basu 1997), or the market-to-book ratio (Beaver and Ryan 2000) as a proxy for accounting conservatism. However, we find that only non-operating accruals and the earnings-return measures are significantly related to the frequency of losses, a finding consistent with the growing literature showing differences among accounting conservatism measures (Watts 2003, Givoly et al. 2004, and Roychowdhury and Watts 2004). To capture different aspects and timing of the business cycle, we use three measures - the yearly change in real gross domestic product ( $\Delta \mathrm{GDP}$ ), the yearly change in industrial production $(\Delta \mathrm{IP})$ and the National Bureau of Economic Research's (NBER) definition of an expansion or recession. Our results are robust to these alternative measures of macroeconomic productivity. 
We also control for time-series trends in the data in two ways. First, we take differences of our model inputs and find that year-to-year changes in the percentage of loss firms are significantly related to changes in the Compustat coverage of small firms, changes in real firm performance, and growth in macroeconomic productivity. In contrast, we find no evidence that changes in the degree of accounting conservatism are associated with changes in loss frequency. Next, we add a trend variable to our levels model and find that our inferences on the non-accounting variables are unchanged.

Lastly, we perform additional analysis to explore why small firms report more losses. We provide evidence that small firms are less diversified, have more idiosyncratic risk, invest more, and are more likely to fail than larger firms. We further find that these firm characteristics are similarly related to loss firms vis-à-vis profit firms. We conclude that the economic fundamentals of small firms contribute to their likelihood of realizing accounting losses over time.

Our study contributes to the literature in several ways. We expand on existing accounting research that examines determinants behind losses by shedding light on how non-accounting factors are associated with negative income, after controlling for accounting conservatism. Moreover, our evidence suggests that non-accounting factors, and firm size in particular, play the dominant role over accounting conservatism in determining losses.

We expand on our result on firm size by exploring reasons why small firms are more likely to report losses than larger firms. Specifically, we show that economic factors intrinsic to small firms make it more likely for these firms to report losses than larger firms. As such, we extend recent findings by Fama and French $(2001,2004)$, who 
report that smaller firms generally report lower earnings than larger firms during their sample periods.

We extend the prior literature on analyzing losses by using annually-aggregated, market-wide data in our main empirical tests rather than firm-specific data. There are several advantages to taking this approach. It allows us to relate macroeconomic variables to losses - in particular, our business cycle variables are time-dependent macroeconomic variables. In addition, aggregating variables annually provides insights into the long-term time trends of our variables, while firm-specific variables do not lend themselves easily to this task. Aggregation also filters out idiosyncratic components of information that are uncorrelated across firms. For example, Kothari et al. (2003) finds that aggregating earnings over time minimizes the effects of noise in firms' earnings. Skinner (2004) makes a similar argument for the relation between dividends and earnings.

Finally, accounting income, and losses in particular, are relevant in determining security valuations, bankruptcy probabilities, and abandonment options. Accounting earnings and losses are inputs in contracting, shareholder litigation, dividend policy, market listing standards, and regulatory inquiries. Our study implies that focusing on accounting conservatism alone could result in poor decision-making.

To illustrate, Hayn (1995) and Joos and Plesko (2005) examine how accounting data influence strings of losses, which in turn, allows managers to better evaluate its firm abandonment option. By discerning non-accounting determinants of losses, managers can better assess the permanence and risks inherent to an observe loss and decide in a timelier manner if and when to cease operations. Similarly, security valuation models using net 
income or changes in net income as independent variables could encompass nonaccounting determinants of losses as additional valuation factors for loss firms.

With regard to contracting, Dichev and Skinner (2002) find that net income frequently is used in accounting-based debt covenants, either directly through a debt to "cash flow" ratio, where cash flow can be cash flows from operations, EBIT, or EBITDA, or indirectly through net worth, where net worth is diminished by accounting losses. They also show that while $30 \%$ of all loans are in technical default, lenders appear to weigh whether violators are in financial distress, and often waive the violations for "healthy" firms. Since most technical defaulters have negative income (Dichev and Skinner 2002; DeFond and Jiambalvo 1994), understanding the fundamentals behind losses would assist lenders in determining when to call the loan. Likewise, boards of directors can construct executive compensation contracts to minimize the effects of macroeconomic factors as it relates to accounting-based bonuses.

The remainder of the paper is organized as follows. We present our hypotheses linking accounting losses to accounting and non-accounting factors in Section 2 and our regression framework in section 3. We describe our data in Section 4 and present main results in section 5. In Section 6, we discuss the results of our robustness tests. In Section 7, we perform additional analysis examining why small firms report more losses. Finally, in Section 8 we summarize and conclude the paper.

\section{HYPOTHESES}

Our study focuses on the associations between accounting losses and nonaccounting factors after controlling for accounting conservatism. In this section, we 
discuss hypotheses linking accounting losses to three non-accounting factors: Compustat coverage of small firms, real performance as measured using cash flows from operations, and macroeconomic productivity. We begin by discussing the already established link between accounting losses and accounting conservatism.

\section{Accounting Conservatism}

Based on Givoly and Hayn's (2000) findings, we expect a positive relation between the frequency of accounting losses and accounting conservatism. Givoly and Hayn (2000) show a decline in ROA and a subsequent increase in non-operating accruals over time for a constant sample of 896 Compustat firms between 1951 and 1998. Their results, along with no marked deterioration in CFO (scaled by total assets) for the same sample, support the hypothesis that the observed decrease in accounting income over time mirrors an increase in accounting conservatism over the same time period.

There are several differences between our study and Givoly and Hayn (2000). One primary distinction is that, in contrast to their study, we use the nearly-universal Compustat database. Other differences are that they use firm-specific data and analyze ROA, whereas we utilize an aggregated approach to study the annual frequency of accounting losses.

\section{Compustat Coverage of Small Firms}

We predict a positive association between the annual percentage of losses and the rise in the percentage of small firms appearing on the Compustat database over time. Our prediction is consistent with Fama and French $(2001,2004)$, who report a temporal 
increase in the percentage of small firms appearing on both the Compustat and CRSP databases, as well as the fact that smaller firms generally report lower earnings than larger firms over their sample period.

There are several possible reasons why small firms are more likely to report losses than larger firms. Many small firms are in the earlier stages of development and therefore are less likely to be reporting positive earnings. Small firms have more volatility in their operations due to being less diversified, being more dependent on fewer customers and/or suppliers, and undertaking more risky investments. Thus, they may alternate between reporting positive earnings and losses. Many small firms are failing companies and therefore are more likely to report losses than larger firms. Thus, we posit that small firms are riskier than larger firms, which in turn, results in higher incidences of accounting losses over time. We provide additional analysis of why small firms report more losses in Section 7.

\section{Business Cycle and Macroeconomic Productivity}

We predict a negative relation between the frequency of accounting losses and macroeconomic productivity. ${ }^{1}$ Business cycles generally are divided into expansions, representing "high" growth rates in economic productivity, and recessions or

\footnotetext{
${ }^{1}$ Examination of links between accounting earnings and macroeconomic factors has been relatively unexplored in the accounting and economic literature. Johnson (1999) documents that earnings response coefficients (ERC) and earnings persistence are related to business cycles. Stern (1955) finds a "fairly close correlation" between contemporaneous industrial production and "money profits in industry" in the United Kingdom and the United States for the years 1919-1950. Chant (1980) reports a positive relation between leading money supply (M1) and current accounting earnings for 1958-1977; Levi (1980) finds a similar association between the change in M1 and the level of accounting earnings for 1949-1975. Chant (1980), however, finds no relation between bank loans and accounting earnings, and Alessi (1964) reports none between inflation and accounting earnings.
} 
contractions, which are declines in economic productivity levels. ${ }^{2}$ Although there are several measures of macroeconomic productivity, two commonly used statistics are the gross domestic product (GDP) and industrial production (IP).

As Hall (1990) shows, there are vast differences in economic variables during expansions and recessions. Using data from 1919 through 1982, he finds that over all expansions, average real GDP rises by 6.0 percent, average real consumption rises by 4.3 percent, and average real investment rises by 27.7 percent. In contrast, the average changes over all recessions are -5.4 percent for real GDP, -0.5 percent for real consumption, and -27.8 percent for real investments. These statistics suggest that firms invest more and that consumers spend more during periods of high macroeconomic productivity and conversely, firms and consumers cut expenditures during periods of low or negative macroeconomic productivity. We predict that these patterns of expenditures will result in higher frequencies of accounting losses during recessions or periods of low economic productivity.

\section{Cash Flows from Operations}

We predict a negative association between the frequency of accounting losses and aggregate cash flows from operations (CFO). CFO include cash transactions involved in the firm's delivering or producing goods or providing services, and therefore, we view it as a measure of the firm's real performance. In Section 5, we present evidence consistent with this view.

\footnotetext{
${ }^{2}$ A full business cycle covers a recession and subsequent expansion. Zarnowitz (1985) defines a full cycle from the trough of one contraction to the trough of the next contraction. He identifies ten business cycles from 1933 through 1982 and 30 business cycles from 1854 through 1982.
} 


\section{REGRESSION FRAMEWORK}

Unlike most accounting studies that use firm-specific data, we adopt a marketwide approach, regressing the annual percentage of accounting losses for the 1951-2001 period on four aggregated accounting and non-accounting variables. ${ }^{3}$ The basic regression is:

$$
\% \operatorname{LOSSES}_{t}=\beta_{0}+\beta_{1} \mathrm{CNSV}_{t}+\beta_{2} \mathrm{SMALL}_{t}+\beta_{3} B U S C Y C_{t}+\beta_{4} C F O A_{t}+\varepsilon_{t}
$$

where $\% L O S S E S_{t}$ is the percentage of Compustat firms reporting accounting losses for year $t, C N S V_{t}$ is a measure of accounting conservatism for year $t, S M A L L_{t}$ is the measure of the relative number of small firms in the Compustat database for year $t, B U S C Y C_{t}$ is a measure of macroeconomic productivity for year $t$, and $C F O A_{t}$ is mean cash flows from operations divided by assets for year $t$.

As described in Section 2, we choose these independent variables because they measure potentially significant aspects of firms' overall earnings processes. In addition, each can be delineated with relative unambiguity as either an accounting or nonaccounting factor. For example, $C N S V$ is clearly an accounting measure in that its magnitude and direction depends greatly on accounting rules over time. SMALL and $B U S C Y C$ basically are unrelated to accounting conservatism - SMALL depends on total assets and BUSCYC measures the productivity of the overall U.S. economy. CFOA is intended to measure real firm performance, a "non-accounting" metric. Even though CFO

\footnotetext{
${ }^{3}$ This approach is widely used in the finance literature to examine market-wide trends in market returns (Fama and French 1992), market volatility (Campbell et al. 2001), the equity premium (Fama and French 2002; Claus and Thomas 2001), dividends (Fama and French 2001) and new listings (Fama and French 2004). Two accounting papers that use aggregated data across time are Skinner (2004), who relates aggregated dividends and earnings, and Kothari et al. (2003) who examine the relation between aggregated earnings and returns.
} 
is an accounting variable, subject to accounting rules, it is relatively less susceptible to manipulation than accounting earnings or accruals (Dechow 1994; Dechow and Schrand 2004). We discuss the associations among our independent variables later in the paper to assess the classification of these independent variables as "accounting" or "nonaccounting" factors.

\section{SAMPLE SELECTION, DATA DEFINITIONS AND DATA DESCRIPTION Sample Selection}

The sample consists of all firm-years for which net income (Compustat item no. 172) and total assets (Compustat item no. 6) are available on the merged Compustat annual industrial file, including PST, full coverage, and research files. This results in 259,719 observations over the period 1951-2001. The total number of firms varies from a low of 614 in 1951 to a high of 10,313 in 1996.

Table 1 presents the annual frequency of losses. The percentages vary from 0.81\% in 1951 to $45.86 \%$ in 2001. Consistent with Hayn (1995), Collins et al. (1997), and Collins et al. (1999), we find that the frequency of losses has risen steadily over time. Frequency rates for each decade are $3.44 \%$ for $1951-1960,7.28 \%$ for $1961-1970,13.95 \%$ for $1971-1980,30.09 \%$ for $1981-1990$, and $35.96 \%$ for $1991-2001$.

\section{Accounting Conservatism}

We use the same accounting conservatism measure as Givoly and Hayn (2000). The firm's non-operating accruals (NOPACC) are defined as total accruals (net income minus cash flows from operations) plus depreciation and amortization minus operating 
accruals $(\Delta$ accounts receivable $+\Delta$ inventories $+\Delta$ prepaid expenses $-\Delta$ accounts payable $\Delta$ taxes payable) divided by beginning period total assets. Removal of these items from total accruals leaves us primarily with gains and losses from non-operating assets, bad debt expense, restructuring charges, write-downs of assets, deferred income taxes, writeoffs of in-process R\&D expenses, and other expenses or revenues not included in the operating accrual accounts. Since most non-operating accruals are expenses or losses, we equate accounting conservatism of the income statement with larger negative amounts.

We choose this measure initially over the Basu (1997) earnings-returns and Beaver and Ryan's (2000) book-to-market value of equity measures for two main reasons. First, NOPACC is based on accounting data only. In contrast, the other two measures are market dependent. Second, several studies (e.g., Dietrich et al. 2003; Givoly et al. 2004) have questioned the reliability of the earnings-return measure as a proxy for accounting conservatism. In fact, Givoly et al. (2004) present evidence of a negative relation between the earnings-return measure and alternative accounting conservatism measures and point to measurement error in the earnings-return measure as a prime reason for these observed observations. In section 6 , we present sensitivity tests in which we use the earnings-returns and book-to-market measures to examine differences among these definitions of accounting conservatism.

Table 2, Panel A shows the mean and median values of NOPACC by decade. NOPACC declines in the 1960s, remains relatively constant in the 1970s, and falls dramatically in the 1980s and 1990s. The large negative growth in NOPACC in the latter period parallels those presented by Givoly and Hayn (2000) for their constant sample of 
896 firms, ending in 1998. Thus, while not monotonic, there nevertheless is a steady rise in accounting conservatism for the full Compustat sample over our time period.

\section{Compustat Coverage of Small Firms}

We estimate SMALL by comparing the total assets of each firm to the population of NYSE firms (see Fama and French 2001, 2004). For each year, we rank all NYSE firms by their total assets and classify as "small" all NYSE, AMEX, and NASDAQ firms that have total assets less than the $25^{\text {th }}$ percentile of NYSE firms.

As Table 2, Panel A shows, both mean and median percentages of all firms on the Compustat tape classified as small rise in the 1960s but explode after 1970 to over $60 \%$ of the total listings. To a great extent, this pattern parallels Compustat's increased coverage of NASDAQ firms during our time period. ${ }^{4} \quad$ For example, in 1950, NASDAQ firms represent 17\% of the available firms on Compustat (105 out of 615). By 1975 this percentage increases to $55 \%$, and in 1997 the percentage is $67 \%$.

In addition, NASDAQ firms are, on average, smaller than exchange-listed firms. For our sample from 1970-2001, the average (median) asset size for NASDAQ firms is $\$ 729.1$ (\$650.2) million, compared to $\$ 3,653.6(\$ 2,594.4)$ million for NYSE-AMEX firms. In fact, despite the success of many NASDAQ firms in the latter period, the differential in asset size actually grew throughout the time period. In 1951, the average NYSE-AMEX firm was 1.07 times larger than the average NASDAQ firm. By 1970, the

\footnotetext{
${ }^{4}$ Unlike the CRSP database, which started covering NASDAQ stocks in 1973, the Compustat database contains NASDAQ-traded stocks throughout our 51 year period. However, the degree of variability in $S M A L L$ is limited in the first 20 years of our sample period due to relatively few AMEX or NASDAQ firms being listed on Compustat. To overcome this potential problem, we use an alternative size measure, the coefficient of variation of the log of total assets (the standard deviation divided by the mean). We obtain similar results with this measure; the estimated coefficient on this variable is significantly different from zero at conventional levels in each regression.
} 
differential was 1.79; by 1992 the average NYSE-AMEX firm was 4.35 times larger than the average NASDAQ firm; and by 2000 the multiple reached 6.84 . There are various reasons behind this phenomenon. One reason is that the NASDAQ has always had less stringent listing requirements than the NYSE or the AMEX. In particular, minimum listing requirements for revenues and assets consistently have been lower for NASDAQtraded firms.

\section{The Business Cycle and Macroeconomic Productivity}

We represent the U.S. business cycle using three alternative measures of macroeconomic productivity. The first measure is an indicator based on the NBER's definition of expansionary and recessionary periods. The NBER divides the U.S. economy into two economic environments: expansions are from the trough to the peak of business growth, where business growth is measured in total output, income, and employment (see also Moore 1983), and recessions are measured from the peak to the trough. The NBER uses monthly data such as changes in retail sales, the unemployment rate, real wages, and industrial production (see www.nber.org and Hall 1990) to delineate peaks and troughs. As shown in Table 2, Panel B, during 1951-2001, there were nine NBER recession periods and nine NBER expansions. We define the variable RECESS as equaling one if any part of a recessionary period occurs within a calendar year and zero otherwise. Other papers using the NBER definition include Johnson (1999) and Chordia and Shivakumar (2002).

The other two measures are the annual percentage change in real gross domestic product $(\triangle G D P)$, and the annual percentage change in total industrial production $(\triangle I P)$. 
GDP is compiled by the U.S. Department of Commerce and includes personal consumption, government expenditures, private investment, inventory growth and the trade balance (see www.BEA.gov). Papers using $\triangle G D P$ as a macroeconomic measure of business productivity include Hall (1990) and Cochrane (1991). Although corporate profits are a component of GDP, we note that from 1979 through 2001, net income (after tax) makes up less than eight percent of GDP (Federal Reserve Bank of St. Louis 2004) and has fluctuated within the 15-17 percent range after World War II (Financial Times 2004). Therefore, examining the relation between accounting losses and $\triangle G D P$ does not necessarily impose a mechanistic relation between the two. IP, like GDP, measures total real output, but is more limited in scope. It is compiled by the Federal Reserve and includes total production in manufacturing, mining, gas and electric utilities (see www.federalreserve.gov). Previous studies using $\triangle I P$ as a measure of business productivity include Fama (1981) and Chordia and Shivakumar (2002). We obtained the data for $\triangle G D P$ and $\triangle I P$ from "Economagic.com: Economic Time Series."

Table 2, Panel A contains the means and medians by decade for $\triangle G D P$ and $\triangle I P$. Unlike the data on NOPACC and SMALL, $\triangle G D P$ and $\triangle I P$ do not trend upwards or downwards over time. Instead, we note a higher growth in $\triangle G D P$ and $\triangle I P$ during the 1960s, followed by a deterioration of economic productivity over the 1970s and 1980s, followed by a subsequent rise in the 1990s.

\section{Cash Flows from Operations}

CFOA is CFO divided by beginning total assets averaged across firms for each year. We define CFO according to GAAP. For the years 1987-2001, CFO is annual 
Compustat item number 308. From 1971-1986, it is funds from operations (item number $110)$ minus the change in working capital $(\Delta$ current assets $+\Delta$ debt in current liabilities $\Delta$ current liabilities - $\Delta$ cash). Prior to $1971, C F O$ is net income before extraordinary items plus depreciation expense plus the change in deferred taxes minus the change in working capital (see Rayburn 1987). ${ }^{5}$

As shown in the last two columns of Table 2, Panel A, CFOA has declined precipitously over time, dropping from a mean (median) of $0.101(0.104)$ in the 1950 s to 0.013 (0.016) in the 1991-2001 period. Consistent with Joos and Plesko (2005), we also note a drop in CFOA from 1971-1990 to 1991-2001. Both our and Joos and Plesko's findings are in contrast to Givoly and Hayn (2000), who find no marked deterioration in CFOA over time. However, Givoly and Hayn (2000) examine a smaller constant-firm sample, which by construction asks a different set of questions than those addressed here. ${ }^{6}$

\section{EMPIRICAL RESULTS}

\section{Empirical Issues}

We estimate equation (1) using RECESS, $\triangle G D P$ and $\triangle I P$ as alternative measures of BUSCYC. Before presenting the results, we discuss several statistical considerations. First, our research design is biased against finding significant coefficients on the business cycle because there is not perfect overlap between the timing of the expansions and

\footnotetext{
${ }^{5}$ As a sensitivity check, we use the Rayburn (1987) definition of CFO for all years and rerun our regression analyses with this variable. The coefficient and significance level on CFO with the Rayburn measure is qualitatively the same as with CFO defined above.

${ }^{6}$ If we limit our analysis to a constant sample over 1951-2001, we similarly find no significant decrease in CFOA over time, consistent with Givoly and Hayn (2000).
} 
contractions and \%LOSSES. That is, \%LOSSES is measured on an annual basis, but business cycles begin and end over varying time periods. Thus, our results will be sensitive to possible mismatching between the business cycles and the accounting measurement period.

Second, as we show in Table 3, there is a great deal of collinearity among the independent variables. For example, $C F O A$ is highly positively correlated with $N O P A C C$ (Pearson $\rho=0.5471 ; \mathrm{p}=0.0001)$ and negatively correlated with SMALL (Pearson $\rho=-$ $0.8134 ; \mathrm{p}=0.0001$ ), implying that the drop in $C F O A$ has mirrored the rise in nonoperating accruals and the percentage of small firms over time. Thus, omitting $C F O A$ from the regression would result in upwardly biased coefficients on NOPACC and SMALL that is due to an omitted correlated variable problem. Similarly, SMALL and NOPACC are highly negatively correlated (Pearson $\rho=-0.4784 ; \mathrm{p}=0.0004$ ), suggesting that omitting either variable from the regression on \%LOSSES would produce an upwardly biased coefficient on the remaining variable. These correlations have implications both for our study and for interpretations of other studies, as they imply that examining bivariate associations between accounting losses (accounting earnings) and a single variable in isolation may result in biased inferences.

Third, CFOA is uncorrelated with the business cycle variables. The Pearson correlation coefficient between CFOA and RECESS is 0.2141 ( $\mathrm{p}=0.1314)$; between $C F O A$ and $\triangle G D P$ it is $0.1039(\mathrm{p}=0.4679)$ and between $C F O A$ and $\triangle I P$ it is 0.0667 $(\mathrm{p}=0.6418)$. These correlations buttress our assertion that $C F O A$ primarily measures firm-specific performance as opposed to being a reflection of the business cycle. 
Fourth, although $C F O A$ is uncorrelated with the business cycle variables, it is related significantly to $\%$ LOSSES (Pearson $\rho=-0.9428 ; \mathrm{p}=0.0001$ ). Therefore, omitting CFOA from regression (1) leads to an upwardly biased estimator of the variance of $\beta_{3}$, leading to an acceptance of the null hypothesis more frequently than is justified by the given level of significance (Kmenta 1971).

\section{Regression Results}

The regressions results are presented in Table 4 . We begin by examining the simple regression of \%LOSSES on accounting conservatism (NOPACC) alone. Consistent with Givoly and Hayn (2000), we find a negative relation between the percentage of accounting losses over time and NOPACC. The regression coefficient on NOPACC is -3.359 , with a $t$-statistic of $-5.62(\mathrm{p}$-value $<0.01)$. Because more negative levels of NOPACC indicate greater accounting conservatism, these findings are consistent with the view that the annual percent of accounting losses is positively related to the degree of accounting conservatism. The adjusted $R^{2}$ is $38.0 \%$ indicating that $38.0 \%$ of the variation in the percentage of annual losses can be explained by accounting conservatism alone. Thus, we corroborate Givoly and Hayn's (2000) results for a larger sample of firms.

In model 2, SMALL is added to the regression. The estimated coefficient on SMALL is 0.796 , with a $t$-statistic of 12.55 (p-value $<0.01$ ). Thus, as predicted, the temporal increase in the percentage of accounting losses is mirrored by the temporal increase in SMALL. The adjusted $R^{2}$ is $85.2 \%$, compared to an adjusted $R^{2}$ of $38.0 \%$ for the simple regression of \%LOSSES on NOPACC. Testing for the incremental 
explanatory power of adding $S M A L L$ yields an $F$-statistic of 67.1 , significant at the $1 \%$ level, supporting the hypothesis that \%LOSSES depends not only on NOPACC, but also on SMALL.

The drop in the estimated coefficient on NOPACC from -3.359 in model 1 to 1.252 in model 2 reflects the -0.59 correlation between NOPACC and SMALL that we documented in Table $3 .^{7}$ Nonetheless, both variables provide significant explanatory power over the frequency of accounting losses even in the presence of this multicollinearity.

In models 3 through 5, we add the business cycle (RECESS, $\triangle G D P$, or $\triangle I P$ ) and cash flows from operations $(C F O A)$ to the multivariate regression. As these regressions show, there are significant associations between \%LOSSES and the business cycle variables. The coefficients on $\triangle G D P$ and $\triangle I P$ are significantly negative at the $1 \%$ level, indicating that \%LOSSES is negatively related to macroeconomic growth. The coefficient on RECESS is significantly positive at the $1 \%$ level; i.e., $\%$ LOSSES are higher for years in which there is a recession.

The coefficients on $C F O A$ are also significantly negative, consistent with the view that accounting losses are negatively related to the company's firm-specific economic productivity. For both regressions, the estimated coefficient on $C F O A$ is statistically significant at the $1 \%$ level. The regression coefficients on SMALL (NOPACC) remain

\footnotetext{
${ }^{7}$ The significant correlation between NOPACC and SMALL raises the question of whether SMALL is truly a "non-accounting" factor, as we claim. Although the two variables are highly correlated, a regression of $N O P A C C$ on SMALL and a time trend variable reveals that only the trend variable is significant in explaining NOPACC levels over time, consistent with our characterization of SMALL as unrelated to accounting conservatism.
} 
significantly positive (negative), with the exception of model 5, in which NOPACC is negative but insignificantly different from zero. ${ }^{8}$

To examine the effects of adding these variables to the model, we compare the coefficients on NOPACC and SMALL from models 3 - 5 to the regression on NOPACC and SMALL alone (model 2). The magnitude of the estimated coefficient on NOPACC drops from -1.252 to -0.491 in model $3,-0.621$ in model 4 , and -0.330 in model 5 . The coefficient on SMALL drops from 0.796 in model 2 to around 0.375 in models 3-5. The explanation behind these declines lies in the significant negative correlations between CFOA and NOPACC and between CFOA and SMALL. That is, adding CFOA to the regression model reduces the biases in these coefficients.

In summary, we find that accounting losses are related to both accounting conservatism and non-accounting factors. Specifically, the percentage of losses is directly related to accounting conservatism and the percentage of small firms on Compustat's database; they are inversely related to the business cycle and to cash flows from operations. Thus, non-accounting fundamentals add significant incremental information about accounting losses over and beyond accounting conservatism.

\footnotetext{
${ }^{8}$ As an alternative measure of cash flows, we use free cash flows instead of cash flows from operations. We define free cash flows as our CFO measure minus capital expenditures (annual Compustat item \#128). The correlation between CFO and free cash flows is 0.94 . When we substitute free cash flows for CFO in models (3) through (5), we find that the results are qualitatively the same, but weaker. For example, in model (4), the adjusted $\mathrm{R}^{2}$ falls to $87.8 \%$ and the intercept becomes insignificantly different from zero. We thus conclude that $\mathrm{CFO}$ is a better indicator of real firm performance than free cash flows.
} 


\section{ROBUSTNESS TESTS}

\section{Using ROA as the Dependent Variable}

In this section, we examine whether our results apply only to losses or whether they can be generalized to net income-to-total assets (hereafter ROA). Givoly and Hayn (2000) define profitability as ROA and show a relation between the deterioration of ROA over time and the rise of accounting conservatism. Since this paper builds on their work, we consider whether our findings hold for ROA over time as well as losses. Further, by understanding the non-accounting fundamentals behind ROA, academics and other users of accounting income can better utilize and interpret net income in general.

We estimate the following regression:

$$
R O A_{t}=\beta_{0}+\beta_{1} N O P A C C_{t}+\beta_{2} S_{M A L L}+\beta_{3} B U S C Y C_{t}+\beta_{4} C F O A_{t}+\varepsilon_{t},
$$

where $R O A_{t}$ is the median ROA for year $t$. We measure ROA as net income (annual Compustat item number 172) divided by beginning period total assets.

Table 5, Panel A presents the mean and median ROA by decade. Consistent with Givoly and Hayn (2000), there is a steady deterioration of ROA over time. In the 1950s, the median ROA is 0.068 . By the $1980 \mathrm{~s}$, the median ROA is less than half that amount (0.031), and it falls by almost 50\% again in the $1990 \mathrm{~s}(0.016)$. The mean ROA shows similar declines, turning negative in the 1980 s and remaining negative throughout the 1990s.

Table 5, Panel B shows the summary statistics for equation (2) using the three definitions of macroeconomic productivity. The results complement those presented in Table 4. The estimated coefficients on SMALL, $\triangle G D P, R E C E S S$, and CFOA are significantly different from zero at the $1 \%$ levels and are in the predicted directions. $\triangle I P$ 
is significantly positive at the $10 \%$ level, and $N O P A C C$, the accounting conservatism variable, is insignificantly different from zero. The adjusted $R^{2}$ values for the regressions with $R O A$ are comparable to those reported with \%LOSSES as the dependent variable. We conclude that the analyses presented thus far are fairly robust to whether we examine determinants behind accounting losses or income levels, in general. In particular, we find that non-accounting factors influence losses and ROA in similar ways.

\section{Alternative Measures of Accounting Conservatism}

Several studies assess alternative measures of accounting conservatism and conclude these measures reflect different aspects of the accounting process (Watts 2003; Givoly et al. 2004; and Roychowdhury and Watts 2004). To examine the extent to which differing accounting conservatism measures affect our regression analyses, we use two commonly-used alternative measures as substitutes for NOPACC.

The first measure is Basu's (1997) earnings-returns (E-R) metric, which is the $\gamma_{2}$ coefficient in the following regression:

$$
E S_{i t} / \text { Price }_{i, t-1}=\alpha_{0}+\alpha_{1} D U M_{i t}+\gamma_{1} \operatorname{RETURN}_{i t}+\gamma_{2}\left(\operatorname{RETURN}_{i t} * D U M_{i t}\right)+\varepsilon_{i t}
$$

where the $i$ and $t$ subscripts denote the firm and year, respectively; EPS is annual earnings per share; Price is the stock price at the beginning of the fiscal year, DUM is a dummy variable equal to one if the stock return is negative and zero otherwise; and RETURN is the year's stock return. Individual stock returns are computed over the twelve-month period beginning nine months prior to the end of fiscal year $t$. Under Basu's (1997) methodology, $\gamma_{2}(E-R)$ is expected to be positive. The underlying notion behind this premise is that, with conservative accounting, earnings reflect bad news more quickly 
than they reflect good news. Thus, we predict a positive relation between $\%$ LOSSES and $E-R$.

The second measure is the annual market-to-book ratio of equity (see Beaver and Ryan 2000). This measure of conservatism recognizes that the market's valuation of a firm's assets and liabilities can differ substantially from the book value of these assets and liabilities. A ratio greater than one indicates accounting conservatism of the balance sheet. Accounting reasons for the discrepancies between market and book value of equity include non-recognition of intangibles (e.g., R\&D, brand names, and market shares), using historical costs instead of market values for property, plant and equipment, and off-balance sheet financings and contingencies. We predict a positive relation between \%LOSSES and the market-to-book ratio $(M B)$.

Table 6, Panel A shows the mean and median values for $E-R$ and $M B$ by decade. Consistent with prior research (e.g., Basu 1997), mean and median $E-R$ increase over time, peaking during the 1980 s, but still remaining relatively high in the 1990s. In contrast, $M B$ increases between the 1950s and 1960s, dips dramatically in the 1960s, then rises precipitously over the next two decades. Comparing $E-R$ and $M B$ to $N O P A C C$ and to each other suggests that the individual accounting conservatism measures are picking up different aspects of financial reporting. ${ }^{9}$

Panel B contains the regression results; models 1-3 present the estimated coefficients on $E-R$, and models 4-6 show the coefficients on $M B$. As Panel B shows, the non-accounting variables, $S M A L L, B U S C Y C$, and $C F O A$ are robust to each accounting conservatism metric. In all six regressions, the coefficients on the non-accounting

\footnotetext{
${ }^{9}$ The Pearson correlation coefficient between NOPACC and $M B$ is $-0.18(\mathrm{p}=0.20)$; the coefficient between $N O P A C C$ and $E-R$ is -0.21 ( $\mathrm{p}=0.14)$; and the coefficient between $M B$ and $E-R$ is $0.03(\mathrm{p}=0.84)$.
} 
variables are statistically significant at conventional levels, with all but one variable significant at the $5 \%$ or $1 \%$ levels.

In contrast, we find very different statistical results for the accounting conservatism variables. In models $1-3, E-R$ is statistically positive at the $5 \%$ or $1 \%$ levels, indicating a significant association between \%LOSSES and the E-R conservatism measure. In models 4-6, the estimated coefficients on $M B$ are insignificantly different from zero, suggesting no relation between $M B$ and accounting losses. Further, when we compare the coefficients in Table 6 to those in Table 4 (where we used NOPACC as our measure of accounting conservatism), we see that using $E-R$ has no tangible affects on the estimated coefficients on BUSCYC and CFOA, but diminishes the coefficient on SMALL. Conversely, using $M B$ has no discernible impact on the coefficients on $B U S C Y C$ and SMALL, but reduces the coefficients on CFOA. We find that the primary causes of these differences are reflected in the correlations between the independent variables. E-R and SMALL have a 0.63 correlation statistic, and $M B$ and $C F O A$ have a correlation coefficient of -0.42 . Thus, consistent with Givoly et al. (2004) and Roychowdhury and Watts (2004), we find differences in accounting conservatism metrics. However, we also find that these differences contribute little to our interpretation of how non-accounting factors relate to accounting losses.

\section{How Important are Time-Series Trends?}

The results reported thus far are based on regressions in which one level variable is regressed on several other level variables. As Table 4 shows, both the $t$-statistics on the coefficients and the $\mathrm{R}^{2}$ value for the full regression are high. However, two of the 
independent variables, $S M A L L$ and $C F O A$, display either upward or downward trends, as does the dependent variable, \%LOSSES. These trends raise several questions. First, are the high $R^{2}$ values reported in Table 4 related to these trends? Second, and perhaps more important, to what extent do these trends contribute to the documented rise in accounting losses over time? Finally, after controlling for the trends, what role does the business cycle play in explaining accounting losses?

We begin answering these questions by noting that the Durbin-Watson statistics for the regressions reported in Table 4 are significant at the $1 \%$ level, suggesting some degree of autocorrelation among the residuals. To control for the autocorrelation in the disturbances in the regression models and to remove possible trends in the data, we perform two separate tests. First, we transform the data into first differences and rerun the regression analyses on the transformed data. The regression model is:

$$
\Delta \% \text { LOSSES }_{t}=\beta_{0}+\beta_{1} \Delta N O P A C C_{t}+\beta_{2} \Delta S M A L L_{t}+\beta_{3} B U S C Y C_{t}+\beta_{4} \Delta C F O A_{t}+\varepsilon_{t},
$$

where $\Delta$ is the one-year change. The subscript $t$ refers to the change between years $t-1$ and $t$. Note that all variables except the business cycle variables $(\triangle G D P, \triangle I P$, and RECESS) have been differenced to take out their trend factors. We do not difference our business cycle variables, as they are already expressed as a change from the prior year.

Second, we incorporate a time trend factor, TREND, into the original levels regression, where TREND is defined as the calendar year minus 1950. The regression model is as follows:

$\% \operatorname{LOSSES}_{t}=\beta_{0}+\beta_{1} N O P A C C_{t}+\beta_{2}$ SMALL $_{t}+\beta_{3}$ BUSCYC $_{t}+\beta_{4}$ CFOA $_{t}+\beta_{5}$ TREND $_{t}+\varepsilon_{t}$.

The difference between (4) and (5) reflects dissimilar statistical artifacts. Equation (4) corrects for the presence of a first degree autocorrelation process in the 
dependent and independent variables. Including the trend factor in equation (5) is a correct procedure for eliminating the presence of a time-stationary process.

Table 7 presents the summary statistics for each regression. In Panel A, $\triangle \%$ LOSSES is significantly related to $\triangle G D P, \triangle I P$, and RECESS at the $1 \%$ levels. Thus, the yearly change in the percentage of losses is significantly related to the business cycle, suggesting that changes in the frequency of accounting losses are exaggerated or attenuated by the business cycle. $\triangle \% L O S S E S$ is also positively and significantly associated with $\triangle S M A L L$, the change in the percentage of small firms in the Compustat database. Thus, as relatively more small firms are added (or removed) each year from Compustat's coverage, the percentage of accounting losses increases or decreases as well. For the two regressions with $\triangle I P$ and RECESS, $\triangle \% L O S S E S$ is significantly negatively related to the annual change in CFOA, supporting our earlier finding that accounting losses are inversely related to cash flows from operations. The main difference between the levels-based and changes-based regressions, however, is in the significance levels for NOPACC vis-à-vis $\triangle N O P A C C$. Whereas in Table $4, N O P A C C$ is significantly negative for two of the three levels-based models, none of the coefficients on $\triangle N O P A C C$ is significantly different from zero in the changes-based models. Thus, over time, there appears to be no systematic relation between changes in the frequency of accounting losses and changes in the degree of accounting conservatism, ceteris paribus.

The adjusted $R^{2}$ values for the models are $32.1 \%, 57.1 \%$ and $30.0 \%$, respectively. Although the explanatory power for the changes regressions are lower than that for the levels regressions, they still suggest that a significant amount of variation in the change in the percentage of losses is picked up by changes in non-accounting variables. The 
Durbin-Watson statistics for each regression are insignificantly different from zero, implying that the autocorrelation factors have been removed. The insignificant coefficients on $\triangle N O P A C C$ and the reduced significance levels on $\triangle S M A L L$ and $\triangle C F O A$ suggest that much of the time-series correction is coming from these three factors.

Table 7, Panel B contains the regression results for the levels-based equation with a time-trend factor included as an additional independent variable. The estimated coefficient on the trend factor is insignificantly different from zero ( $t$-statistics range from 1.18 to 1.28 ) for the three regressions. In addition, the interpretation of the independent variables with respect to their relation to \%LOSSES is unaffected by the inclusion of a time-trend factor. However, consistent with the changes-based regressions, the $t$ statistics on SMALL and CFOA drop dramatically from those reported in Table 4. For

example, for the regression using $\triangle G D P$ to measure macroeconomic productivity , the $t$ statistic for SMALL drops from 6.55 in Table 4 to 3.02 in Table 7. Similarly, the $t$ statistic for $C F O A$ declines from -8.82 to -4.88 . In contrast, there is little to no change in the $t$-statistics for NOPACC or for the business cycle variables. Thus, as with the changes-based analysis, adding the trend factor corrects for the time-series properties of the SMALL and CFOA variables.

\section{WHY DO SMALL FIRMS REPORT MORE LOSSES?}

Our results are consistent with the view that that the increasing percentage of small firms on Compustat is a major reason for the increase in the percentage of firms reporting losses over time. In our hypothesis section, we posited several reasons behind this phenomenon: small firms are less diversified, they are more risky, and they are more 
likely to be in the early or later stages of their life cycle. In this section, we investigate the associations among small firms, losses, and these variables.

First, we posit that small firms are less diversified. If small firms are less diversified, then they are limited in their abilities to offset losses from one line of business against gains from another line of business. One direct way to measure this is to compare the number of reporting segments between small and other firms. Firms with only one segment are the least able to offset losses. We therefore predict that small firms are more likely to be single-segmented. We also predict that the likelihood of reporting a loss is higher for firms with a single business segment.

Second, we propose that small firms have more volatility in their operations and therefore are more likely to report losses in one year and profits in another year. In contrast, larger firms have more smoothed performances in their operations and consequently are less likely to report losses in any given year. One way to measure operations volatility is to examine the idiosyncratic component of the firm's variance of daily stock returns over the year. Campbell et al. (2001) specifically link idiosyncratic stock volatility to the variance of cash-flow shocks. We predict that small firms have higher idiosyncratic risk than larger firms, and consequently, the likelihood of a firm reporting a loss is positively related to its idiosyncratic risk over time.

Third, we posit that small firms are more likely to be in the beginning or ending stages of their life cycles. Fama and French (2004) show that from 1980-1989, 89.7 percent of new common stock listings (IPOs and non-IPOs) were in the zero to twentieth percentile of market equity based on all stocks trading on the NYSE in the month of the listing. From 1990-2000, 72.0 percent of new listings were in the zero to twentieth 
percentile of market equity. Fama and French (2004) also demonstrate that the percentage of new listings reporting accounting losses in their first year was 44.2 percent in 1980-1989 and 44.2 percent in 1990-2000 for IPOs, and was 44.6 percent in 19891989 and 51.6 percent in $1990-2000$ for non-IPO new listings. Taken together, their results suggest that many small firms are in the beginning of their life cycle and that newly-listed firms have a high probability of showing an accounting loss in its listing year. We therefore propose that firm size is positively related to it being a new listing and that the likelihood of a firm reporting an accounting loss is positively related to whether it is a new listing. We also hypothesize that small firms in the earlier stages of development invest more heavily in long-term assets and research and development than larger firms and so are less likely to be reporting positive cash flows from operations and/or positive net income. We therefore posit that small firms will have more negative CFI (with R\&D included) than larger firms and that the likelihood of a firm reporting an accounting loss is negatively related to its investing cash flows.

Barth et al. (1998) show that firms delisting from Compustat because of bankruptcy between 1975-1993 have, in the year prior to delisting, mean assets of $\$ 133.85$ million and mean net income of $-\$ 67.93$ million. They also demonstrate that over 1988 - 1993, financially healthier firms have substantially higher market values of equity and net income than firms with lower financial health. Their findings suggest that many small firms are in the end of their life-cycle and that these firms are more likely to report losses in their delisting year. Consequently, we posit that small firms are more frequently delisted and that accounting losses are related to whether a firm delists. 
Data on the number of business segments are from Compustat's segment detail file. SEG1 is a dummy variable equal to one if the firm has only one business segment and zero otherwise. Segment data are available from 1985 onwards. Idiosyncratic risk (IDVOL) is the standard deviation of the residual from a firm-specific regression of daily returns on the equally-weighted CRSP market portfolio returns, estimated annually. $N E W$ is a dummy variable equal to one if the firm appears for the first time in year $t$ on the Compustat tape and zero otherwise. DELIST is a dummy variable equal to one if the firm's history on the Compustat research tape ends at year $\mathrm{t}$ and zero otherwise. CFI is cash flows from investing (annual Compustat item 311) minus research and development expense (annual Compustat item 46), divided by total assets. These data are available from 1987 onwards.

We perform both univariate and multivariate analyses. Because our data on CFI begin in 1987, we limit our analysis to firms listed on Compustat in 1987-2001. Since this gives us only fifteen years of data, we do not use annually-aggregated data; instead we use firm specific data. Thus, SMALLFIRM is a dummy variable equal to one if the firm is at or below the $25^{\text {th }}$ percentile of NYSE assets for that year and zero otherwise. LOSSFIRM is a dummy variable equal to one is the firm has negative net income in that year and zero otherwise.

Table 8, Panel A presents the univariate tests on differences in firm characteristics for small/large firms and for loss/profit firms. As the panel shows, small firms are significantly more likely to have only one business segment, have greater idiosyncratic risk, have proportionally higher numbers of delistings, and have more negative CFI than larger firms. Specifically, on average, 79.08 percent of small firms have one business 
segment compared to 56.98 percent of large firms (t-statistic for differences between means $=65.45$, significant at $>0.001$ level). Small firms' idiosyncratic risk is 0.0536 , compared to 0.0264 for large firms (t-statistic $=163.47$, significant at the $>0.001$ level). CFI is -0.1340 for small firms, against -0.1120 for large firms (t-statistic $=-17.92$, significant at the $>0.001$ level). On average, 7.12 percent of small firms delist compared to 4.93 percent of large firms that delist (t-statistic $=12.35$, significant at the $>0.001$ level). On average, however, there is no difference between the percentages of new listings between small and large firms (t-statistic $=1.55$, insignificant at the 0.10 level). Thus, small firms are less diversified, more risky, have more negative levels of investing cash flows and are more likely to be at the end of their life cycles than larger firms. Comparing median values produce similar results and conclusions.

As the right side of Panel A shows, there are similar mappings in firm characteristics for loss firms vis-à-vis profit firms. The percentage of loss firms with only one reporting segment is significantly greater than the percentage of profit firms 75.66 percent against 65.27 percent $\left(\mathrm{t}\right.$-statistic $=28.43$, significant at the $>0.001$ level) ${ }^{10}$ Loss firms' idiosyncratic risk is 0.0583 compared to 0.0322 for profit firms (t-statistic $=$ 122.45, significant at the $>0.001$ level). ${ }^{11}$ Loss firms invest more heavily than profit firms - CFI is -0.1427 for loss firms and -0.1141 for profit firms ( $\mathrm{t}$-statistic $=18.33$, significant

\footnotetext{
${ }^{10} \mathrm{We}$ also examine the number of segments itself and find similar results. Small firms have, on average, 1.35 business segments whereas larger firms have, on average, 2.02 business segments ( $\mathrm{t}$-statistic $=75.88$ ). Loss firms, on average, have 1.47 business segments and profit firms have 1.76 business segments (tstatistic $=33.81$ ). We also note, however, that during our time period, there was a change in reporting standards regarding segment reporting. SFAS 131 became effective for fiscal years beginning on or after January 1, 1998. Two outcomes of the change was that more firms reported in greater numbers of lines of businesses and that fewer firms reported just one business segment (see Street et al. 2000). These results work against our hypothesis since the percentage of firms reporting losses after 1997 rose but the percentage of firms reporting one segment dropped.

${ }^{11}$ This finding complements Ertimur (2005), who finds that loss firms have higher levels of information asymmetry than profit firms.
} 
at the $>0.001$ level). On average, 8.35 percent firms delist in a loss year compared to 4.96 percent of firms that delist in a profitable year (t-statistic $=16.55$, significant at the $>0.001$ level). Comparing medians produce similar results and conclusions, with only median CFI not being statistically different from each other.

In Panel B, we present multivariate probit analyses of SMALLFIRM and LOSSFIRM on the same firm characteristics. Because firms appear repeatedly from yearto-year, we show both pooled-regression and Fama-MacBeth coefficients and test statistics. As Panel B shows, the probit models yield similar results to the univariate analyses. SMALLFIRM is significantly and positively related to SEG1 and IDVOL and is significantly and negatively related to CFI. The evidence on NEW and DELIST is mixed, with $N E W$ being significantly positive for the pooled-sample results only and DELIST being significantly positive for the Fama-MacBeth results only. LOSSFIRM is significantly and positively related to SEG1, IDVOL, NEW, and DELIST and is significantly negatively related to $C F I$.

In summary, we provide some intuition behind the finding that small firms are more likely to report losses than larger firms. We show that in 1987-2001, small firms are less diversified, have higher idiosyncratic risk, more negative levels of CFI (including R\&D expenditures), and are more likely to be at the end of their life cycle than larger firms. We also show that firms with similar characteristics are more likely to record an accounting loss for the year than a profit. 


\section{SUMMARY AND CONCLUSIONS}

This paper examines accounting and non-accounting fundamentals behind accounting losses over the fifty-year period 1951-2001. We examine four factors: accounting conservatism, Compustat coverage of small firms, real firm performance as measured by operating cash flows, and macroeconomic productivity. Consistent with previous studies, we find a positive relation between the frequency of firms reporting negative income over time and accounting conservatism, where accounting conservatism is defined as non-operating accruals (Givoly and Hayn 2000). However, in the overall scheme of our analyses, accounting conservatism appears to play a relatively small role in determining the frequency of losses. Instead, we find accounting losses to be significantly related to the non-accounting factors we examine. Our results also hold when relating ROA to the same factors and are robust to alternative definitions of accounting conservatism and business cycle variables.

Our study makes the following two contributions. First, we expand on extant research that examines the determinants of accounting losses. Consistent with prior studies, we document a significant association between losses and accounting conservatism. Our contribution arises by demonstrating that non-accounting factors, most notably firm size and the business cycle, also play significant roles in explaining the incidence of accounting losses over time.

Second, our study has implications regarding the efficient use of accounting loss information. Accounting income, and losses in particular, are relevant for determining security valuations, bankruptcy probabilities, and abandonment options. Accounting earnings and losses are inputs in contracting, shareholder litigation, dividend policy, 
market listing standards, and regulatory inquiries. By improving our understanding of how losses are generated, users and practitioners can better interpret the meaning of accounting losses.

The study has several limitations. First, our use of cash flows from operating activities as our measure of real firm performance may be imperfect due to manipulation of cash flows. The recent cases of Worldcom and Parmalat demonstrate that cash flow manipulation is a real possibility, and Roychowdhury (2004) empirically finds that firms manage earnings through manipulation of real activities that affect cash flows. However, because it appears that this phenomenon is relatively new, our use of a long time-series of data from 1951-2001 should mitigate its effects. In addition, Roychowhury's (2004) findings suggest a negative relation between accounting losses and cash flows, not a positive one, as we document. Nonetheless, the possibility of cash flow manipulation should be kept in mind when interpreting the results.

Second, we take an aggregate, market-wide approach to examining the fundamentals of accounting losses. While this research design choice has the advantage of allowing us to incorporate macroeconomic conditions into our analysis, which is one of our primary objectives, it precludes analyses and inferences regarding firm-specific variables, for example, interactions between accounting losses and firms' decisions on how to finance its investments, its dividend policy, changes to its labor force, etc. We leave these analyses to future studies.

Lastly, while our results clearly indicate that non-accounting factors are significant determinants of reported accounting losses, future research might more directly address the implications of these findings. For example, should the use of loss 
information in security valuation, bankruptcy prediction, or credit rating determinations be conditioned on current macroeconomic productivity, firm size, or real firm performance? This is one possible avenue of inquiry that future research might explore. 


\section{REFERENCES}

Alessi, L. 1964. Do business firms gain from inflation? Journal of Business 37: 162-166.

Barth, M. E., W. H. Beaver, and W. R. Landsman. 1998. Relative valuation roles of equity book value and net income as function of financial health. Journal of Accounting and Economics 25: 1-34.

Basu, S. 1997. The conservatism principle and the asymmetric timelines of earnings. Journal of Accounting \& Economics 24: 3-38.

Beaver, W. and S. Ryan. 2000. Biases and lags in book value and their effects on the ability of the book-to-market ratio to predict book return on equity. Journal of Accounting Research:

Campbell, J. Y., M. Lettau, B. G. Malkiel, and Y. Xu, 2001, Have individual stocks become more volatile? An empirical exploration of idiosyncratic risk, Journal of Finance 56: 1-43.

Chant, P. D. 1980. On the predictability of corporate earnings per share behavior. Journal of Finance 35: 13-21.

Chordia, T., and L. Shivakumar. 2002. Momentum, business cycle, and time-varying expected returns. Journal of Finance 57: 985-1019.

Claus, J., and J. Thomas. 2001. Equity premia as low as three percent? Empirical evidence from analysts' earnings forecasts for domestic and international stock markets. The Journal of Finance 56: 1629-1666.

Cochrane, J. H. 1991, Production-based asset pricing and the link between stock returns and economic fluctuations. The Journal of Finance 46: 209-238.

Collins, D. W., E. L. Maydew, and I. S. Weiss. 1997. Changes in the value-relevance of earnings and book values over the past forty years. Journal of Accounting \& Economics 24: 39-68.

Collins, D. W., M. Pincus, and H. Xie. 1999. Equity valuation and negative earnings: The role of book value of equity. The Accounting Review 74: 29-62.

Dechow, P. M. 1994. Accounting earnings and cash flows as measures of firm performance: The role of accounting accruals. Journal of Accounting and Economics 18: 3-42.

Dechow, P. M., and C. M. Schrand. 2004. Earnings Quality. Research Foundation of CFA Institute. 
DeFond, M. L., and J. Jiambalvo. 1994. Debt covenant violation and manipulation of accruals, Journal of Accounting and Economics 17: 145-176.

Dichev, I. D., and D. J. Skinner. 2002. Large sample evidence on the debt covenant hypothesis. Journal of Accounting Research 40: 1091-1123.

Dietrich, J. R., K. L. Muller, and E.J. Riedl. 2003. Using stock returns to determine "bad" versus "good" news to examine the conservatism of accounting earnings. Working paper. Pennsylvania State University.

Ertimur, Y. 2005. Accounting numbers and information asymmetry: Evidence from loss firms. Working paper, Stanford University.

Fama, E. F. 1981. Stock returns, real activity, inflation, and money. American Economic Review 71: 545-565.

Fama, E. F., and K. R. French. 1992. The cross-section of expected stock returns. The Journal of Finance 47: 427-465.

Fama, E. F., and K. R. French. 2001. Disappearing dividends: changing firm characteristics or lower propensity to pay? The Journal of Financial Economics 60: 3-44.

Fama, E. F., and K. R. French. 2002. The equity premium. Journal of Finance 57: 637659.

Fama, E. F., and K. R. French. 2004. New lists and seasoned firms: Fundamentals and survival rates. Journal of Financial Economics 73: 229-269.

Federal Reserve Bank of St. Louis. 2004. Public officials and job creation. National Economic Trends. http://research.stlouisfed.org/publications/net/past/2004.

Financial Times. 2004. The Short View: US Profits Hit a Record Share of GDP.

Givoly, D., and C. Hayn. 2000. The changing time-series properties of earnings, cash flows and accruals: Has financial reporting become more conservative? Journal of Accounting and Economics 29: 287-320.

Givoly, D., C. Hayn, and A. Natarajan. 2004. Measuring reporting conservatism. Working paper. Pennsyvania State University, UCLA, and California State University at Pomona.

Hall, T. E., 1990. Business Cycles: The Nature and Causes of Economic Fluctuations. New York: Praeger Publishers. 
Hayn, C. 1995. The information content of losses. Journal of Accounting \& Economics 20: $125-154$.

Johnson, M. F. 1999. Business cycles and the relation between security returns and earnings. Review of Accounting Studies 4: 93-118.

Joos, P., and G. Plesko. 2005. Valuing loss firms. Accounting Review forthcoming.

Kmenta, J. 1971. Elements of Econometrics. New York: Macmillan Publishing.

Kothari, S. P., Jonathan W. Lewellen, and Jerold B. Warner. 2003. Stock returns, aggregate earnings surprises, and behavioral finance. Working paper, MIT.

Levi, M. D. 1980. Money and corporate earnings. Journal of Money, Credit, and Banking 12: 84-93.

Moore, G. H. 1983. Business Cycles, Inflation, and Forecasting. Cambridge, Mass.: Ballinger Publishing Company.

Rayburn, J. 1987. The association of operating cash flow and accruals with security returns. Journal of Accounting Research 24 (supplement): 112-133.

Roychowdhury, S. 2004. Management of earnings through the manipulation of real activities that affect cash flow from operations. Working paper, MIT.

Roychowdhury, S., and R. L. Watts. 2004. Asymmetric timeliness of earnings, market-tobook and conservatism in financial reporting. Working paper, MIT.

Skinner, Douglas J. What do dividends tell us about earnings quality? 2004. Working paper. University of Michigan.

Stern, E. H. 1955. Industrial production and profits in the United Kingdom and the United States. The Economic Journal 65: 485-497.

Street, D. L., N. B. Nichols, and S. J. Gray. 2000. Segment disclosures under SFAS No. 131: Has business segment reporting improved? Accounting Horizons 14: 259285.

Watts, R. 2003. Conservatism in accounting part II: Evidence and research opportunities, Accounting Horizons 17, 287-301.

Zarnowitz, V. 1985. Recent work on business cycles in historical perspective: A review of theories and evidence. Journal of Economic Literature 23: 523-580. 
TABLE 1

Frequency of Accounting Losses by Year

\begin{tabular}{|c|c|c|c|c|c|}
\hline Year & $\begin{array}{c}\text { Total } \\
\text { number of } \\
\text { firms }\end{array}$ & $\%$ of losses & Year & $\begin{array}{c}\text { Total } \\
\text { number of } \\
\text { firms }\end{array}$ & $\%$ of losses \\
\hline 1951 & 614 & $0.81 \%$ & 1979 & 5,875 & $13.14 \%$ \\
\hline 1952 & 625 & $1.76 \%$ & 1980 & 5,988 & $16.35 \%$ \\
\hline 1953 & 636 & $1.42 \%$ & 1981 & 6,076 & $19.55 \%$ \\
\hline 1954 & 653 & $2.91 \%$ & 1982 & 6,327 & $25.51 \%$ \\
\hline 1955 & 674 & $1.78 \%$ & 1983 & 6,604 & $25.92 \%$ \\
\hline 1956 & 692 & $2.17 \%$ & 1984 & 6,658 & $26.65 \%$ \\
\hline 1957 & 712 & $1.97 \%$ & 1985 & 6,940 & $31.43 \%$ \\
\hline 1958 & 735 & $3.54 \%$ & 1986 & 7,256 & $33.13 \%$ \\
\hline 1959 & 763 & $2.23 \%$ & 1987 & 7,350 & $33.33 \%$ \\
\hline 1960 & 1,372 & $9.40 \%$ & 1988 & 7,250 & $32.63 \%$ \\
\hline 1961 & 1,699 & $8.18 \%$ & 1989 & 7,176 & $34.56 \%$ \\
\hline 1962 & 1,918 & $6.20 \%$ & 1990 & 7,203 & $35.37 \%$ \\
\hline 1963 & 2,169 & $6.32 \%$ & 1991 & 7,366 & $36.32 \%$ \\
\hline 1964 & 2,334 & $5.36 \%$ & 1992 & 7,798 & $34.87 \%$ \\
\hline 1965 & 2,489 & $4.06 \%$ & 1993 & 8,901 & $32.00 \%$ \\
\hline 1966 & 2,666 & $4.01 \%$ & 1994 & 9,310 & $28.94 \%$ \\
\hline 1967 & 2,846 & $4.88 \%$ & 1995 & 10,108 & $31.48 \%$ \\
\hline 1968 & 3,430 & $5.80 \%$ & 1996 & 10,313 & $32.14 \%$ \\
\hline 1969 & 3,634 & $8.91 \%$ & 1997 & 10,056 & $33.99 \%$ \\
\hline 1970 & 3,704 & $15.31 \%$ & 1998 & 10,303 & $39.25 \%$ \\
\hline 1971 & 3,895 & $13.71 \%$ & 1999 & 10,257 & $40.13 \%$ \\
\hline 1972 & 4,076 & $8.88 \%$ & 2000 & 9,531 & $41.75 \%$ \\
\hline 1973 & 4,467 & $8.46 \%$ & 2001 & 7,967 & $45.86 \%$ \\
\hline 1974 & 5,885 & $16.86 \%$ & $1951-60$ & 7,476 & $3.44 \%$ \\
\hline 1975 & 5,917 & $18.34 \%$ & $1961-70$ & 26,889 & $7.28 \%$ \\
\hline 1976 & 5,953 & $14.53 \%$ & $1971-80$ & 54,001 & $13.95 \%$ \\
\hline 1977 & 6,009 & $13.91 \%$ & $1981-90$ & 68,840 & $30.09 \%$ \\
\hline \multirow[t]{2}{*}{1978} & 5,936 & $12.37 \%$ & 1991-01 & 101,910 & $35.96 \%$ \\
\hline & & & All years & 259,719 & $25.84 \%$ \\
\hline
\end{tabular}

Variable Definition

Accounting losses are negative values of net income (Compustat item no. 172). 


\section{TABLE 2}

\section{Descriptive Statistics}

\begin{tabular}{|c|c|c|c|c|c|c|c|c|c|c|}
\hline \multirow{2}{*}{$\begin{array}{c}\text { Time } \\
\text { Period } \\
\end{array}$} & \multicolumn{2}{|c|}{$N O P A C C$} & \multicolumn{2}{|c|}{$S M A L L$} & \multicolumn{2}{|c|}{$\triangle G D P$} & \multicolumn{2}{|c|}{$\Delta I P$} & \multicolumn{2}{|c|}{ CFOA } \\
\hline & Mean & $\underline{\text { Median }}$ & Mean & Median & Mean & Median & Mean & Median & Mean & Median \\
\hline $1951-60$ & -0.011 & -0.007 & 0.285 & 0.274 & 0.035 & 0.032 & 0.028 & 0.035 & 0.101 & 0.104 \\
\hline $1961-70$ & -0.015 & -0.018 & 0.452 & 0.438 & 0.042 & 0.045 & 0.054 & 0.056 & 0.084 & 0.087 \\
\hline $1971-80$ & -0.015 & -0.015 & 0.592 & 0.617 & 0.032 & 0.040 & 0.035 & 0.042 & 0.074 & 0.073 \\
\hline $1981-90$ & -0.034 & -0.032 & 0.641 & 0.640 & 0.032 & 0.035 & 0.019 & 0.024 & 0.041 & 0.036 \\
\hline $1991-2001$ & -0.052 & -0.043 & 0.665 & 0.665 & 0.033 & 0.038 & 0.032 & 0.038 & 0.013 & 0.016 \\
\hline
\end{tabular}

\section{Panel B: NBER Definitions of Recession/Expansion Subperiods}

$\underline{\text { Recession }}$

Aug 1953 - May 1954

Sept 1957 - Apr 1958

May 1960 - Feb 1961

Jan 1970 - Nov 1970

Dec 1973 - Mar 1975

Feb 1980 - July 1980

Aug 1981 - Nov 1982

Aug 1990 - Mar 1991

Apr 2001 - Dec 2001

\section{Expansion}

Nov 1949 - Jul 1953

Jun 1954 - Aug 1957

May 1958 - Apr 1960

Mar 1961 - Dec 1969

Dec 1970 - Nov 1973

Apr 1975 - Jan 1980

Aug 1980 - Jul 1981

Dec 1982 - July 1990

Apr 1991 - Mar 2001

\footnotetext{
Variable Definitions

NOPACC, or non-operating accruals, is defined as total accruals (net income - cash flow from operations) minus operating accruals ( $\Delta$ accounts receivable $+\Delta$ inventories $+\Delta$ prepaid expenses $-\Delta$ accounts payable- $\Delta$ taxes payable) plus depreciation and amortization expenses, all divided by beginning period total assets.
}

SMALL is the percentage of Compustat firms whose total assets are less than $25^{\text {th }}$ percentile of the total assets of firms listed on the New York Stock Exchange for that year.

$\triangle$ GDP is the annual percentage change in real gross domestic product, compiled by the U.S. Department of Commerce. $\triangle \mathrm{IP}$ is the annual percentage change in total industrial production, compiled by the Federal Reserve.

CFOA is cash flows from operations divided by beginning period total assets. For the years 1987-2001, we use Compustat item no. 308. From 1971-1986, CFO is funds from operations minus $\Delta$ working capital ( $\Delta$ current assets $+\Delta$ short-term debt $-\Delta$ current liabilities $-\Delta$ cash). Prior to 1971, CFO is net income before extraordinary items plus depreciation expense plus $\Delta$ deferred income taxes $-\Delta$ working capital).

The National Bureau of Economic Research (NBER) divides the U.S. economy into two economic environments: expansions and recessions. Expansions are from the trough to the peak of business growth and recessions are from the peak to trough of business growth. 


\begin{tabular}{|c|c|c|c|c|c|c|c|}
\hline \multicolumn{8}{|c|}{$\begin{array}{c}\text { TABLE } 3 \\
\begin{array}{c}\text { Correlation Coefficients Among Frequency of Losses, Accounting Conservatism, Percentage } \\
\text { of Small Firms, Macroeconomic Productivity, and CFO }\end{array}\end{array}$} \\
\hline Variable & $\% L O S S E S$ & NOPACC & $S M A L L$ & RECESS & $\triangle G D P$ & $\Delta I P$ & CFOA \\
\hline$\% L O S S E S$ & $\begin{array}{c}1.0000 \\
(0.0000)\end{array}$ & $\begin{array}{c}-0.5567 \\
(0.0001)\end{array}$ & $\begin{array}{c}0.9031 \\
(0.0001)\end{array}$ & $\begin{array}{l}-0.0507 \\
(0.7237)\end{array}$ & $\begin{array}{l}-0.2066 \\
(0.1458)\end{array}$ & $\begin{array}{l}-0.1965 \\
(0.1669)\end{array}$ & $\begin{array}{c}-0.9425 \\
(0.0001)\end{array}$ \\
\hline$N O P A C C$ & $\begin{array}{c}-0.5163 \\
(0.0001)\end{array}$ & $\begin{array}{c}1.0000 \\
(\mathbf{0 . 0 0 0 0 )}\end{array}$ & $\begin{array}{c}-0.4784 \\
(0.0004)\end{array}$ & $\begin{array}{c}0.3536 \\
(0.0109)\end{array}$ & $\begin{array}{c}-0.3040 \\
(0.0301)\end{array}$ & $\begin{array}{c}0.0339 \\
(0.8134)\end{array}$ & $\begin{array}{c}0.5471 \\
(0.0001)\end{array}$ \\
\hline$S M A L L$ & $\begin{array}{c}0.8741 \\
(0.0001)\end{array}$ & $\begin{array}{c}-0.5850 \\
(0.0001)\end{array}$ & $\begin{array}{c}1.0000 \\
(\mathbf{0 . 0 0 0 0})\end{array}$ & $\begin{array}{c}-0.0854 \\
(0.5511)\end{array}$ & $\begin{array}{c}-0.1829 \\
(0.1990)\end{array}$ & $\begin{array}{c}-0.1693 \\
(0.2351)\end{array}$ & $\begin{array}{c}-0.8134 \\
(0.0001)\end{array}$ \\
\hline RECESS & $\begin{array}{l}-0.0205 \\
(0.8867)\end{array}$ & $\begin{array}{c}0.4035 \\
(0.0033)\end{array}$ & $\begin{array}{c}-0.1637 \\
(0.2510)\end{array}$ & $\begin{array}{c}1.0000 \\
(0.0000)\end{array}$ & $\begin{array}{r}-0.7422 \\
(0.0001)\end{array}$ & $\begin{array}{r}-0.6092 \\
(0.0001)\end{array}$ & $\begin{array}{c}0.2141 \\
(0.1314)\end{array}$ \\
\hline$\triangle G D P$ & $\begin{array}{c}-0.2512 \\
(0.0754)\end{array}$ & $\begin{array}{c}-0.2744 \\
(0.0514)\end{array}$ & $\begin{array}{c}-0.1345 \\
(0.3468)\end{array}$ & $\begin{array}{c}-0.7133 \\
(0.0001)\end{array}$ & $\begin{array}{c}1.0000 \\
(0.0000)\end{array}$ & $\begin{array}{c}0.5421 \\
(0.0001)\end{array}$ & $\begin{array}{c}0.1039 \\
(0.4679)\end{array}$ \\
\hline$\triangle I P$ & $\begin{array}{l}-0.2268 \\
(0.1096)\end{array}$ & $\begin{array}{c}0.0070 \\
(0.9609)\end{array}$ & $\begin{array}{l}-0.1555 \\
(0.2760)\end{array}$ & $\begin{array}{l}-0.5760 \\
(0.0001)\end{array}$ & $\begin{array}{c}0.5602 \\
(0.0001)\end{array}$ & $\begin{array}{c}1.0000 \\
(0.0000)\end{array}$ & $\begin{array}{c}0.0667 \\
(0.6418)\end{array}$ \\
\hline CFOA & $\begin{array}{c}-0.9203 \\
(0.0001)\end{array}$ & $\begin{array}{c}0.5752 \\
(0.0001)\end{array}$ & $\begin{array}{c}-0.8622 \\
(0.0001)\end{array}$ & $\begin{array}{c}0.2280 \\
(0.1075)\end{array}$ & $\begin{array}{c}0.1386 \\
(0.3321)\end{array}$ & $\begin{array}{c}0.0985 \\
(0.4916)\end{array}$ & $\begin{array}{c}1.0000 \\
(0.0000)\end{array}$ \\
\hline
\end{tabular}

Pearson (Spearman) correlation coefficients are presented above (below) the diagonal. P-values are presented in parentheses.

Variable Definitions

$\%$ LOSSES is the percentage of accounting losses reported for each year.

NOPACC is non-operating accruals defined as total accruals (net income - cash flow from operations) minus operating accruals $(\Delta$ accounts receivable $+\Delta$ inventories $+\Delta$ prepaid expenses $-\Delta$ accounts payable$\Delta$ taxes payable) plus depreciation and amortization expenses, all divided by beginning period total assets.

SMALL is the percentage of Compustat firms whose total assets are less than $25^{\text {th }}$ percentile of the total assets of firms listed on the New York Stock Exchange for that year.

RECESS equals one if the year is included in an NBER recession period, and zero otherwise. The National Bureau of Economic Research (NBER) divides the U.S. economy into two economic environments: expansions and recessions. Expansions are from the trough to the peak of business growth and recessions are from the peak to trough of business growth. $\triangle$ GDP is the annual percentage change in real gross domestic product Real GDP is compiled monthly by the U.S. Department of Commerce. $\Delta$ IP is the annual percentage change in total industrial production. It is compiled monthly by the Federal Reserve.

CFOA is cash flows from operations divided by beginning period total assets. For the years 1987-2001, we use Compustat item no. 308. From 1971-1986, CFO is funds from operations minus $\Delta$ working capital ( $\Delta$ current assets $+\Delta$ short-term debt $-\Delta$ current liabilities $-\Delta$ cash). Prior to 1971 , CFO is net income before extraordinary items plus depreciation expense plus $\Delta$ deferred income taxes $-\Delta$ working capital). 


\section{TABLE 4}

\section{OLS Regressions of Frequency of Losses on Accounting Conservatism, Percentage of Small Firms, Macroeconomic Productivity, and CFO}

\begin{tabular}{|c|c|c|c|c|c|c|}
\hline Model & Intercept & NOPACC & SMALL & $B U S C Y C$ & $C F O A$ & $\operatorname{Adj.} R^{2}$ \\
\hline 1 & $\begin{array}{c}0.095 * * * \\
(4.36)\end{array}$ & $\begin{array}{c}-3.359 * * * \\
(-5.62)\end{array}$ & & & & $38.0 \%$ \\
\hline 2 & $\begin{array}{c}-0.180 * * * \\
(-7.40)\end{array}$ & $\begin{array}{c}-1.252 * * * \\
(-3.72)\end{array}$ & $\begin{array}{c}0.796 * * * \\
(12.55)\end{array}$ & & & $85.2 \%$ \\
\hline $\begin{array}{c}3 \\
\beta_{3}=R E C E S S\end{array}$ & $\begin{array}{c}0.150 * * * \\
(4.22)\end{array}$ & $\begin{array}{c}-0.491 * * * \\
(-3.36)\end{array}$ & $\begin{array}{c}0.374 * * * \\
(7.04)\end{array}$ & $\begin{array}{c}0.041 * * * \\
(4.43)\end{array}$ & $\begin{array}{c}-2.408 * * * \\
(-10.36)\end{array}$ & $95.6 \%$ \\
\hline $\begin{array}{c}4 \\
\beta_{3}=\Delta G D P\end{array}$ & $\begin{array}{c}0.167 * * * \\
(4.29)\end{array}$ & $\begin{array}{c}-0.621 * * \\
(-2.61)\end{array}$ & $\begin{array}{c}0.376^{* * *} \\
(6.55)\end{array}$ & $\begin{array}{c}-0.001 * * * \\
(-3.29)\end{array}$ & $\begin{array}{c}-2.181 * * * \\
(-8.82)\end{array}$ & $94.9 \%$ \\
\hline $\begin{array}{c}5 \\
\beta_{3}=\Delta I P\end{array}$ & $\begin{array}{c}0.168 * * * \\
(4.14)\end{array}$ & $\begin{array}{l}-0.330 \\
(-1.44)\end{array}$ & $\begin{array}{c}0.378 * * * \\
(6.36)\end{array}$ & $\begin{array}{c}-0.002 * * * \\
(-2.74)\end{array}$ & $\begin{array}{c}-2.328 * * * \\
(-9.09)\end{array}$ & $94.6 \%$ \\
\hline
\end{tabular}

$*, * *$, and $* * *$ indicate statistical significance at the $10 \%, 5 \%$, and $1 \%$ levels, respectively, using a twotailed test. In panel B, $t$-statistics are presented in parentheses.

Variable Definitions

$\%$ LOSSES is the percentage of accounting losses reported for each year.

NOPACC is mean non-operating accruals, defined as total accruals (net income - cash flow from operations) minus operating accruals ( $\Delta$ accounts receivable $+\Delta$ inventories $+\Delta$ prepaid expenses $\Delta$ accounts payable- $\Delta$ taxes payable) plus depreciation and amortization expenses, all divided by beginning period total assets.

SMALL is the percentage of Compustat firms whose total assets are less than $25^{\text {th }}$ percentile of the total assets of firms listed on the New York Stock Exchange for that year.

BUSCYC is the U.S. business cycle. We represent BUSCYC using three different measures. The National Bureau of Economic Research (NBER) divides the U.S. economy into two economic environments: expansions and recessions. Expansions are from the trough to the peak of business growth and recessions are from the peak to trough of business growth. RECESS equals one if the year is included in an NBER recession period, and zero otherwise. $\triangle \mathrm{GDP}$ is the annual percentage change in real gross domestic product Real GDP is compiled monthly by the U.S. Department of Commerce. $\Delta$ IP is the annual percentage change in total industrial production. It is compiled monthly by the Federal Reserve.

CFOA is cash flows from operations divided by beginning period total assets. For the years 1987-2001, we use Compustat item no. 308. From 1971-1986, CFO is funds from operations minus $\Delta$ working capital ( $\Delta$ current assets $+\Delta$ short-term debt $-\Delta$ current liabilities $-\Delta$ cash). Prior to 1971 , CFO is net income before extraordinary items plus depreciation expense plus $\Delta$ deferred income taxes $-\Delta$ working capital). 
TABLE 5

Using Return on Assets (ROA) as the Dependent Variable

\section{Panel A: ROA By Decade}

$\begin{array}{lrc}\frac{\text { Time Period }}{1951-1960} & \frac{\text { Mean }}{0.072} & \frac{\text { Median }}{0.068} \\ 1961-1970 & 0.056 & 0.054 \\ 1971-1980 & 0.042 & 0.047 \\ 1981-1990 & -0.023 & 0.031 \\ 1991-2001 & -0.096 & 0.016\end{array}$

\section{Panel B: OLS Regressions of ROA on Accounting Conservatism, Percentage of Small Firms, Macroeconomic Productivity, and CFO}

$$
\begin{array}{cccccccc}
\multicolumn{6}{c}{\text { ROA }_{t}=\beta_{0}+\beta_{I} N O P A C C_{t}+\beta_{2} S M A L L_{t}+\beta_{3} B U S C Y C_{t}+\beta_{4} C F O A_{t}+\varepsilon_{t}} \\
\text { Model } & \text { Intercept } & \text { NOPACC } & \text { SMALL } & \text { BUSCYC } & \text { CFOA } & \text { Adj. } R^{2} \\
1 & 0.027^{* * *} & -0.010 & -0.027^{* * *} & 0.001^{* * *} & 0.405^{* * *} & 94.8 \% \\
\beta_{3}=\Delta G D P & (4.39) & (-0.26) & (-2.99) & (3.59) & (11.54) & \\
2 & & & & & & \\
\beta_{3}=R E C E S S & 0.024 * * * & 0.010 & -0.027 * * * & -0.001^{* * *} & 0.430^{* * *} & 92.8 \% \\
3 & (3.73) & (0.26) & (-2.86) & (-2.86) & (10.41) & \\
\beta_{3}=\Delta I P & 0.025^{* * *} & -0.032 & -0.029^{* * *} & 0.0003^{*} & 0.449^{* * *} & 92.2 \% \\
& (3.64) & (-0.82) & (-2.85) & (1.85) & (10.32) &
\end{array}
$$

$*, * *$, and $* * *$ indicate statistical significance at the $10 \%, 5 \%$, and $1 \%$ levels, respectively, using a twotailed test. In panel B, $t$-statistics are presented in parentheses.

Variable Definitions

$R O A$ is the median return on assets for all firms in year $\mathrm{t}$.

NOPACC, non-operating accruals, is defined as total accruals (net income - cash flow from operations) minus operating accruals $(\Delta$ accounts receivable $+\Delta$ inventories $+\Delta$ prepaid expenses $-\Delta$ accounts payable$\Delta$ taxes payable) plus depreciation and amortization expenses, all divided by beginning period total assets.

SMALL is the percentage of Compustat firms whose total assets are less than $25^{\text {th }}$ percentile of the total assets of firms listed on the New York Stock Exchange for that year.

BUSCYC is the U.S. business cycle. We represent Buscyc using three different measures. The National Bureau of Economic Research (NBER) divides the U.S. economy into two economic environments: expansions and recessions. Expansions are from the trough to the peak of business growth and recessions are from the peak to trough of business growth. RECESS equals one if the year is included in an NBER recession period, and zero otherwise. $\triangle \mathrm{GDP}$ is the annual percentage change in real gross domestic 
product Real GDP is compiled monthly by the U.S. Department of Commerce. $\Delta$ IP is the annual percentage change in total industrial production. It is compiled monthly by the Federal Reserve.

CFOA is cash flows from operations divided by beginning period total assets. For the years 1987-2001, we use Compustat item no. 308. From 1971-1986, CFO is funds from operations minus $\Delta$ working capital ( $\Delta$ current assets $+\Delta$ short-term debt $-\Delta$ current liabilities $-\Delta$ cash). Prior to 1971 , CFO is net income before extraordinary items plus depreciation expense plus $\Delta$ deferred income taxes $-\Delta$ working capital). 


\section{TABLE 6}

Sensitivity Analysis for Alternative Accounting Conservatism Measures

\section{Panel A: Alternative Conservatism Measures by Decade}

\begin{tabular}{ccccc} 
Time Period & $\begin{array}{c}\text { Earnings-Return Measure }(E-R) \\
\text { Mean }\end{array}$ & $\frac{2}{\text { Median }}$ & $\frac{\text { Market-to-Book Ratio(MB) }}{2.02}$ & $\frac{\text { Median }}{2.03}$ \\
\hline $1951-1960$ & 0.093 & 0.122 & 2.61 & 2.39 \\
$1961-1970$ & 0.110 & 0.105 & 1.64 & 1.30 \\
$1971-1980$ & 0.296 & 0.318 & 2.49 & 2.80 \\
$1981-1990$ & 0.408 & 0.422 & 3.02 & 3.39 \\
$1991-2000$ & 0.365 & 0.309 &
\end{tabular}

Panel B: OLS Regression of Frequency of Losses on Alternative Accounting Conservatism Measures, Percentage of Small Firms, Macroeconomic Productivity and CFO

\begin{tabular}{|c|c|c|c|c|c|c|}
\hline Model & Intercept & $E-R$ & SMALL & $B U S C Y C$ & $C F O A$ & Adj. $R^{2}$ \\
\hline $\begin{array}{c}1 \\
\beta_{3}=\Delta G D P\end{array}$ & $\begin{array}{c}0.277^{* * *} \\
(5.66)\end{array}$ & $\begin{array}{c}0.130^{* * *} \\
(3.88)\end{array}$ & $\begin{array}{l}0.125^{*} \\
(1.97)\end{array}$ & $\begin{array}{l}-0.005^{* *} \\
(-2.44)\end{array}$ & $\begin{array}{c}-2.883^{* * *} \\
(-11.54)\end{array}$ & $93.6 \%$ \\
\hline $\begin{array}{c}2 \\
\beta_{3}=\Delta I P\end{array}$ & $\begin{array}{c}0.210^{* * *} \\
(5.71)\end{array}$ & $\begin{array}{l}0.082^{* *} \\
(2.59)\end{array}$ & $\begin{array}{c}0.280^{* * *} \\
(4.21)\end{array}$ & $\begin{array}{c}-0.002^{* * *} \\
(-2.63)\end{array}$ & $\begin{array}{c}-2.565^{* * *} \\
(11.79)\end{array}$ & $94.1 \%$ \\
\hline \multirow[t]{2}{*}{$\begin{array}{c}3 \\
\beta_{3}=R E C E S S\end{array}$} & $\begin{array}{c}0.251^{* * *} \\
(5.94)\end{array}$ & $\begin{array}{c}0.111^{* * *} \\
(3.36)\end{array}$ & $\begin{array}{l}0.145^{* *} \\
(2.37)\end{array}$ & $\begin{array}{c}0.035^{* * *} \\
(3.22)\end{array}$ & $\begin{array}{c}-3.003^{* * *} \\
(-12.72)\end{array}$ & $94.1 \%$ \\
\hline & Intercept & $M B$ & SMALL & $B U S C Y C$ & CFOA & Adj. $R^{2}$ \\
\hline $\begin{array}{c}4 \\
\beta_{3}=\Delta G D P\end{array}$ & $\begin{array}{c}0.236^{* * *} \\
(3.55)\end{array}$ & $\begin{array}{l}-0.007 \\
(-0.75)\end{array}$ & $\begin{array}{c}0.382^{* * *} \\
(4.34)\end{array}$ & $\begin{array}{l}-0.005^{* *} \\
(-2.17)\end{array}$ & $\begin{array}{c}-3.327^{* * *} \\
(-13.42)\end{array}$ & $91.9 \%$ \\
\hline $\begin{array}{c}5 \\
\beta_{3}=\Delta I P\end{array}$ & $\begin{array}{c}0.244^{* * *} \\
(3.69)\end{array}$ & $\begin{array}{l}-0.007 \\
(-0.82)\end{array}$ & $\begin{array}{c}0.356^{* * * *} \\
(4.04)\end{array}$ & $\begin{array}{l}-0.002^{* *} \\
(-2.28)\end{array}$ & $\begin{array}{c}-3.377^{* * *} \\
(-13.84)\end{array}$ & $91.9 \%$ \\
\hline $\begin{array}{c}6 \\
\beta_{3}=R E C E S S\end{array}$ & $\begin{array}{c}0.206^{* * *} \\
(3.26)\end{array}$ & $\begin{array}{l}-0.003 \\
(-0.37)\end{array}$ & $\begin{array}{c}0.381^{* * *} \\
(4.58)\end{array}$ & $\begin{array}{c}0.040^{* * *} \\
(3.23)\end{array}$ & $\begin{array}{c}-3.457^{* * *} \\
(-14.92)\end{array}$ & $92.7 \%$ \\
\hline
\end{tabular}


Variable Definitions

$\%$ OOSSES is the percentage of accounting losses reported for each year.

$E-R$ is the estimated coefficient $\gamma_{2}$ from the following annual cross-sectional regression: $\mathrm{EPS}_{i t} / \mathrm{Price}_{i t-1}=\alpha_{0}$ $+\alpha_{l} \mathrm{DUM}_{i t}+\gamma_{0} \operatorname{Return}_{i t}+\gamma_{l}\left(\operatorname{Return}_{i t}{ }^{*} \mathrm{DUM}_{i t}\right)+\varepsilon_{i t}$, where EPS $\mathrm{B}_{i t}$ is the earnings per share of firm $i$ in fiscal year $t$, Price , $_{i,-l}$ is the price per share at the beginning of the fiscal year, Return ${ }_{i t}$ is the return of firm $i$ over the 12 months beginning nine months prior to the end of the fiscal year $t$, and $\mathrm{DUM}_{i t}$ is a dummy variable set equal to one if $\mathrm{R}_{i t}$ is negative and 0 otherwise.

$M B$ is market price per share divided by book value per share at the end of the fiscal year.

SMALL is the percentage of Compustat firms whose total assets are less than $25^{\text {th }}$ percentile of the total assets of firms listed on the New York Stock Exchange for that year.

BUSCYC is the U.S. business cycle. We represent BUSCYC using three different measures. The National Bureau of Economic Research (NBER) divides the U.S. economy into two economic environments: expansions and recessions. Expansions are from the trough to the peak of business growth and recessions are from the peak to trough of business growth. RECESS equals one if the year is included in an NBER recession period, and zero otherwise. $\triangle \mathrm{GDP}$ is the annual percentage change in real gross domestic product Real GDP is compiled monthly by the U.S. Department of Commerce. $\Delta$ IP is the annual percentage change in total industrial production. It is compiled monthly by the Federal Reserve.

CFOA is cash flows from operations divided by beginning period total assets. For the years 1987-2001, we use Compustat item no. 308. From 1971-1986, CFO is funds from operations minus $\Delta$ working capital ( $\Delta$ current assets $+\Delta$ short-term debt $-\Delta$ current liabilities $-\Delta$ cash). Prior to 1971 , CFO is net income before extraordinary items plus depreciation expense plus $\Delta$ deferred income taxes $-\Delta$ working capital). 


\section{TABLE 7}

\section{Examination of Time-Series Trends in the Data}

\section{Panel A: OLS Regression of Change in Percentage of Accounting Losses on Changes in Accounting Conservatism, Percentage of Small Firms, Macroeconomic Productivity, and CFO}

\begin{tabular}{|c|c|c|c|c|c|c|}
\hline Model & Intercept & $\triangle N O P A C C$ & $\triangle S M A L L$ & $B U S C Y C$ & $\triangle \mathrm{CFOA}$ & Adj. $\mathrm{R}^{2}$ \\
\hline $\begin{array}{c}1 \\
\beta_{3}=\Delta G D P\end{array}$ & $\begin{array}{c}0.027^{* * *} \\
(4.33)\end{array}$ & $\begin{array}{c}0.035 \\
(0.19)\end{array}$ & $\begin{array}{l}0.370^{* *} \\
(2.01)\end{array}$ & $\begin{array}{c}-0.006^{* * *} \\
(-4.01)\end{array}$ & $\begin{array}{l}-0.316 \\
(-0.93)\end{array}$ & $32.1 \%$ \\
\hline $\begin{array}{c}2 \\
\beta_{3}=\Delta I P\end{array}$ & $\begin{array}{c}0.019^{* * *} \\
(5.79)\end{array}$ & $\begin{array}{l}-0.107 \\
(-0.72)\end{array}$ & $\begin{array}{l}0.249^{*} \\
(1.68)\end{array}$ & $\begin{array}{c}-0.004^{* * *} \\
(-7.19)\end{array}$ & $\begin{array}{l}-1.10^{* * *} \\
(-3.73)\end{array}$ & $57.1 \%$ \\
\hline $\begin{array}{c}3 \\
\beta_{3}=R E C E S S\end{array}$ & $\begin{array}{l}-0.003 \\
(-0.78)\end{array}$ & $\begin{array}{l}0.035 \\
(0.19)\end{array}$ & $\begin{array}{c}0.410^{* *} \\
(2.21)\end{array}$ & $\begin{array}{c}0.029^{* * *} \\
(3.78)\end{array}$ & $\begin{array}{l}-0.671^{*} \\
(-1.86)\end{array}$ & $30.0 \%$ \\
\hline
\end{tabular}

Panel B: OLS Regression of Percentage of Accounting Losses Accounting Conservatism, Percentage of Small Firms, Macroeconomic Productivity, CFO, and a Trend Factor

\begin{tabular}{|c|c|c|c|c|c|c|c|}
\hline Model & Intercept & NOPACC & SMALL & $B U S C Y C$ & $C F O A$ & TREND & Adj. $R^{2}$ \\
\hline $\begin{array}{c}1 \\
\beta_{3}=\Delta G D P\end{array}$ & $\begin{array}{c}0.142^{* * * *} \\
(3.21)\end{array}$ & $\begin{array}{c}-0.575^{* *} \\
(-2.40)\end{array}$ & $\begin{array}{c}0.286^{* * *} \\
(3.02)\end{array}$ & $\begin{array}{c}-0.007^{\text {*** }} \\
(-3.24)\end{array}$ & $\begin{array}{c}-1.842^{\text {*** }} \\
(-4.88)\end{array}$ & $\begin{array}{l}0.002 \\
(1.18)\end{array}$ & $94.9 \%$ \\
\hline $\begin{array}{c}2 \\
\beta_{3}=\Delta I P\end{array}$ & $\begin{array}{c}0.140^{* * *} \\
(3.07)\end{array}$ & $\begin{array}{l}-0.285 \\
(-1.24)\end{array}$ & $\begin{array}{c}0.278^{* * *} \\
(2.85)\end{array}$ & $\begin{array}{c}-0.002^{* * *} \\
(-2.75)\end{array}$ & $\begin{array}{c}-1.953^{* * *} \\
(-5.02)\end{array}$ & $\begin{array}{c}0.002 \\
(1.27)\end{array}$ & $94.7 \%$ \\
\hline $\begin{array}{c}3 \\
\beta_{3}=R E C E S S\end{array}$ & $\begin{array}{c}0.125^{* * *} \\
(3.10)\end{array}$ & $\begin{array}{c}-0.449^{* *} \\
(-2.13)\end{array}$ & $\begin{array}{c}0.284^{* * *} \\
(3.23)\end{array}$ & $\begin{array}{c}0.041^{* * *} \\
(4.41)\end{array}$ & $\begin{array}{c}-2.065^{* * *} \\
(-5.85)\end{array}$ & $\begin{array}{c}0.002 \\
(1.28)\end{array}$ & $96.7 \%$ \\
\hline
\end{tabular}

\footnotetext{
$*, * *$, and $* * *$ indicate statistical significance at the $10 \%, 5 \%$, and $1 \%$ levels, respectively, using a twotailed test. In panel B, $t$-statistics are presented in parentheses.

Variable Definitions

$\%$ OOSSES is the percentage of accounting losses reported for each year.

NOPACC, non-operating accruals, is defined as total accruals (net income - cash flow from operations) minus operating accruals $(\Delta$ accounts receivable $+\Delta$ inventories $+\Delta$ prepaid expenses $-\Delta$ accounts payable$\Delta$ taxes payable) plus depreciation and amortization expenses, all divided by beginning period total assets.
} 
SMALL is the percentage of Compustat firms whose total assets are less than $25^{\text {th }}$ percentile of the total assets of firms listed on the New York Stock Exchange for that year.

BUSCYC is the U.S. business cycle. We represent Buscyc using three different measures. The National Bureau of Economic Research (NBER) divides the U.S. economy into two economic environments: expansions and recessions. Expansions are from the trough to the peak of business growth and recessions are from the peak to trough of business growth. RECESS equals one if the year is included in an NBER recession period, and zero otherwise. $\triangle$ GDP is the annual percentage change in real gross domestic product Real GDP is compiled monthly by the U.S. Department of Commerce. $\Delta$ IP is the annual percentage change in total industrial production. It is compiled monthly by the Federal Reserve.

CFOA is cash flows from operations divided by beginning period total assets. For the years 1987-2001, we use Compustat item no. 308. From 1971-1986, CFO is funds from operations minus $\Delta$ working capital ( $\Delta$ current assets $+\Delta$ short-term debt $-\Delta$ current liabilities $-\Delta$ cash). Prior to 1971 , CFO is net income before extraordinary items plus depreciation expense plus $\Delta$ deferred income taxes $-\Delta$ working capital).

TREND equals the calendar year minus 1950.

In Panel A, $\Delta$ indicates the change as the value in year $t$ minus the value in year $t-1$. 


\section{TABLE 8}

Differences in the Characteristics of Small vs. Large and Loss vs. Profit Firms (1987 - 2001)

Panel A: Univariate differences in firm characteristics

\begin{tabular}{|c|c|c|c|c|c|c|}
\hline Variable & $\begin{array}{l}\text { Small Firms } \\
(n=38,015)\end{array}$ & $\begin{array}{c}\text { Large Firms } \\
(n=33,397)\end{array}$ & $\begin{array}{c}\text { Test statistic of } \\
\text { difference between } \\
\text { means } / \text { medians } / \%\end{array}$ & $\begin{array}{l}\text { Loss Firms } \\
(n=23,912)\end{array}$ & $\begin{array}{c}\text { Profit Firms } \\
(\mathrm{n}=47,500)\end{array}$ & $\begin{array}{l}\text { Test statistic of } \\
\text { difference between } \\
\text { means/medians }\end{array}$ \\
\hline
\end{tabular}

\begin{tabular}{|c|c|c|c|c|c|c|}
\hline \multicolumn{7}{|l|}{ SEG1 } \\
\hline Percentage & 0.7908 & 0.5698 & $65.45 * * *$ & 0.7566 & 0.6527 & $28.43 * * *$ \\
\hline \multicolumn{7}{|l|}{$I D V O L$} \\
\hline Mean & 0.0536 & 0.0264 & $163.47 * * *$ & 0.0583 & 0.0322 & $122.45 * * *$ \\
\hline Median & 0.0473 & 0.0226 & $157.56 * * *$ & 0.0522 & 0.0275 & $127.08 * * *$ \\
\hline \multicolumn{7}{|l|}{$C F I$} \\
\hline Mean & -0.1340 & -0.1120 & $-17.92 * * *$ & -0.1427 & -0.1141 & $-18.33 * * *$ \\
\hline Median & -0.0955 & -0.0890 & $-6.62 * * *$ & -0.0886 & -0.0926 & 0.92 \\
\hline \multicolumn{7}{|l|}{$N E W$} \\
\hline Percentage & 0.0752 & 0.0722 & 1.55 & 0.0701 & 0.0756 & $-2.68 * *$ \\
\hline \multicolumn{7}{|l|}{ DELIST } \\
\hline Percentage & 0.0712 & 0.0493 & $12.35 * * *$ & 0.0835 & 0.0496 & $16.55 * * *$ \\
\hline
\end{tabular}

Panel B: Multivariate probit analysis of firm size and accounting losses on firm characteristics $(\mathbf{n}=\mathbf{7 1 , 4 1 2 )}$

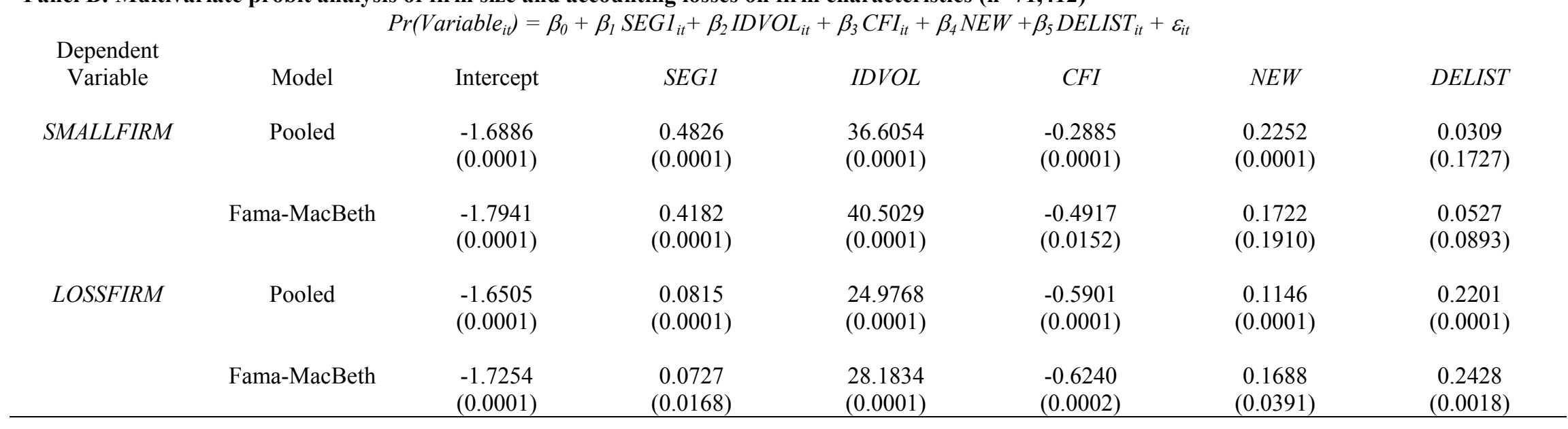


SMALLFIRM is an indicator variable that equals one if the total assets of the firm are less than the $25^{\text {th }}$ percentile of total assets for NYSE firms in a given year and zero otherwise. LOSSFIRM is an indicator variable that equals one if net income is negative and zero otherwise. SEG1 is an indicator variable that equals one if the firm has a single business segment and zero otherwise. IDVOL is the idiosyncratic component of daily stock return volatility, estimated each firm-year by regressing daily returns on the CRSP equally-weighted market return and computing the standard deviation of the residuals. CFI is cash flows from investing activities minus R\&D expenses, divided by total assets. $N E W$ is an indicator variable that equals one if the firm appears for the first time on the annual industrial Compustat tape and zero otherwise. DELIST is an indicator variable that equals one in the last year that the firm appears on the Compustat Research tape. $* * * * * *$ indicate significance at the $0.05,0.01$, and 0.0001 levels, respectively. 